\title{
Integration and Harmonization Strategy in Multicultural Society at Palu City
}

\author{
Haslinda B. Anriani`
}

\begin{abstract}
This research reveals the strategy of the people in Palu City in realizing the integration and harmonization among those with diverse cultural backgrounds. This research has an important position considering the conflict that had taken place in Palu City. Therefore, qualitative research was conducted via in-depth interviews in Palu City community, selecting the main informants from the two major ethnic groups, namely Kaili ethnic as indigenous ethnic and Buginese ethnic as ethnic migrants. The informants asked several questions about the social interaction between the local ethnic and the ethnic migrants and their socio economic and political lives. This interview technique was supported by observation and literature studies related to this research problem. The data was then analyzed descriptively qualitative. The result of the research shows: (1) Palu City community is open to multiculturalism, (2) integration strategy is done in the form of joint activities at Rukun Tetangga (RT, neighbourhood, is the lowest administrative division of Indonesia under Rukun Warga/RW)/Rukun Warga (RW, hamlet) level such as Cleaning Saturday, Sport and Art Contest in RT/RW level, RT/RW gathering, (3) the government cooperates with society to realize social harmony in Palu City.
\end{abstract}

\section{Keywords:}

strategy; integration; harmonization; people; multicultural.

\section{Introduction}

Conflict dynamics in Indonesia have always been destructive and anarchic. This is evidenced by various conflicts such as the cases of Ambon, Poso, Maluku and Palu in Central Sulawesi and the other various cases that fueled greater and more dangerous conflict (Utsman, 2007). This social conflict of ethnicity, religion, race, and inter-groups are not underestimated and must be immediately over and proportional in order not to create national disintegration. There are many things that need to be pondered and scrutinized with the phenomenon of social conflict. Is this social conflict phenomenon an incidental event with certain motives and momentary interest, or is it a culture in a latent society? This empirical reality also shows us there is still a fundamental problem of the collection of doctrines on the one hand and the religious attitude embodied in cultural behavior on the other.

The plurality of such local people is not only horizontal (ethnic, religious and so on) but also often vertical, i.e, the polarization of status and social class based on wealth and position or occupation. Firstly, the development of the

- Universitas Tadulako Palu.

Email: haslinda.tadulako@gmail.com 
market influences certain groups of people, especially ethnic people who are trading traditions. This ethnic group (most of them are migrants) will dominate the trading in the market and impact the social jealousy of the local people, which degrades its development. In the second case, certain ethnic and religious groups, originally outside the mainstream, are on the periphery and are beginning to penetrate into the middle of the mainstream. This can lead to primordial friction, especially when certain political and economic interests occur in Ambon, Poso, Aceh, and others.

In a multicultural society, such as Palu City, the dialogical or mutual understanding is needed to overcome negative accesses from a nation's disintegration problem. This is a necessity because, in recent years, the people of Palu City have social destabilization in the form of ethnic conflict (Taufan, 2013).

At the same time, the people of Palu City make various efforts to create a harmonious and peaceful community. Research results of Aepu et al., (2015) revealed that in order to achieve this, they do 'consensus by involving the government as the owner of authorities.

As a follow-up of various efforts made by various parties to realize the conducive social conditions of the community, this paper reveals another effort of institutional strengthening at the grassroots level. In this context, this paper presents the process of the realization of such efforts so that rational considerations are acceptable.

\section{Methods}

This research is a descriptive qualitative analysis that aims to reveal integration strategies and harmonization of multicultural society in Palu City. For that, an in-depth interview conducted on selected informants consisted of Kaili ethnic (indigenous people), Bugis ethnic, ethnic Makassar, ethnic Javanese, ethnic Gorontalo (migrants), chairman of RT/RW and the sub district's staff. They asked about matters relating to the development of interethnic relation and its impact on conflict, and the integration and harmonization strategies were undertaken. In completing the interview data, the interaction process of people in RT/ RW level was observed. In addition, a literature study of related research results, textbooks on multiculturalism, and archives of local government was conducted. All this data was then categorized and classified by indicator, and finally analyzed and the conclusions were related to the research problem.

\section{Result and Discussion}

\section{Pattern of Multicultural Development in Palu City}

The people of Palu City are very heterogeneous. The residents who live in this city come from various ethnic groups, such as Bugis, Toraja and Mandar from South Sulawesi and West Sulawesi, Gorontalo, Manado, Java, Arab, Tionghoa, and Kaili, which is the original ethnic group and the largest in Central Sulawesi. The diversity of the ethnic group is interpreted by indigenous people or local people as a meaning of openness in social life.

As one of the promising destination cities of breadwinners on the mainland of Sulawesi, the population of Palu City has increased the population from time to time. The increase is an urban social consequence that attracts migrants.

In this research, we can see the various impacts of the multicultural development as social dynamics in Palu City, as follows:

\section{a. Economic Aspect}

In general, there are different orientations shown by the Palu community both are by local communities and migrants as part of their respective ethnic characteristics. For migrants, their main interest is mostly to look for life. This has more to do with the economics of a practical nature. This condition is generally shown by Bugis ethnic who are scattered in almost all 
corners of Palu, especially in areas with large population densities.

The orientation of economic action of the dominant Bugis ethnic was expressed by Mr. Muhammad Risfan in North Palu, a government employee and native Kaili ethnic of Palu:

"If in the field of economy, many migrants who are mainly Bugis ethnic who work as daily needs traders. There are also Javanese who generally open a meatball stalls, the Padang with his restaurant. For local people, there are also selling, but the local nature of a small-scale economy. Most of them are cigarettes seller, drinking seller, vegetables seller, and so forth."

Most of the Bugis migrants developed their economies to the middle, and upper scales, such as having a kiosk in the market, the shop houses they rent to others. In fact, some of them work as housing developers. For example, in Mamboro area of North Palu, the condition is seen differently. Mr. Iwan, who works as head of the public service section at the sub district office, said:

"The environment here....the most dominant is the migrants who do a lot of business. For example, kiosks trade and even there is also a BTN developer here. But, that's where the Kaili ethnic might influences because here it does not know what it is, but there is also Kaili who trade here but the most dominant forward here is the newcomer."

The different professions are seen also in Taipa of North Palu. This is told by Mr. Asri as a Kaili where the area dominated by local communities is compared to the relatively unaccounted number of migrants communities. He recounts:
"If the local residents in this Subdistrict Taipa....we still dominate because it is still the less migrant community. We are here about 80 $90 \%$ still local people. Here also associated with the income society that still many people who involve in the company because here is the industrial area. It is still strong in kinship because of the original social environment. The migrants community is small because usually, that comes also still as sales of mixed goods."

The overall economic condition of local indigenous people with migrants was expressed by several informants on the following interview:

Rustam, a civil servant citizen Kaili, states that as a small trader, his income is uncertain. It is also similar with other sellers, such as binte seller, and fried bananas seller. However, he was helped by receiving a salary from the state.

The same condition is also told by Robin Slamet of Kayu Malue that in his area, there are many farm laborers working in household industries and economic crafts. He said:

"Here the local community... there are 14 farmer groups, then farm labor has not been recorded, and work in the industry and also here there is a handicraft work like that from an economic point of view. With the group of Migrants, here doing a small business, for example, kiosk, owner of the owner of the indigenous people here native Malue Wood here, there are some small business actors that there are also other entrepreneurs who business Bali slaughterhouses are also included large."

The interview above presents an acknowledgment to the economies of local residents who are still in moderate phase with 
small and practical type of work or no longterm impact. At the same time, the migrants' work is mostly in the middle to upper level and they have a chance to be rich.

\section{b. Social Aspect}

In this research, the aspect of social relations that took place in Palu City was placed in a broad context. It related to the relationships between individuals, the relationships between social institutions, the relationships between individuals and social institutions, and human relationships in various contexts such as economics, political relations, religious relations, and other forms of relationships.

Mrs. Zulihariyanti, a junior high school teacher from Java, said that the indigenous people and migrants in the neighborhood are mutually cooperative. Wahyudi Lawide, a retired from Besusu Barat, said that it happened because it was still a local custom.

In another area, Mr. Abdullah, an entrepreneur in Mamboro, illustrated that Kaili ethnic with Bugis have no problems in their relationships. Most Kaili ethnic worked as Food and beverage seller. Bugis ethnic who worked in industrial park came to them at rest time for lunch. The same condition also occurs in Lere subdistrict where Kaili ethnic are dominant $(75 \%)$ but there has never any problem between Kaili ethnic and Bugis, Gorontalo, or Jawa ethnic. Their neigbourhood ran well. It is reinforced by Mr. Halim from West Besusu that the Kaili ethnic are mostly traders and that they are needed by others. This means their existence is very important.

The condition stated by Mr. Abdullah and Mr. Halim above showed that the people in Mamboro and Lere area have good social relationships. The forms of social relationships are manifested in society, such as mutual assistance, mutual need in terms of trade as buyer and seller, and the nature of human nature itself that requires other people to be friends or community.
The social process as described above proved that the ongoing social relationships will continue to occur in various forms based on space and time. Nevertheless, human or social structures can take rational action as a social construction step to realize the goal of multiculturalism.

\section{c. Political Aspect}

The perception of politics for informants is very diverse. Some understand it as a practical political activity such as legislative and electoral elections. They are also regarded as a democracy in the form of joint deliberation. Some see it as a relationship that dominates.

Mr. Rustam, an indigenous person, told of political developments and how they faced a dilemma. He said:

\begin{abstract}
"About the development of politic, for example, the parliament election. If other people (migrants) enter here so we are arranged by them, but otherwise, if we spur the local people to go there and they have not ability, most of this local society only selfish interest and group."
\end{abstract}

The same situation was faced also by Mr. Risfan and Mr. Asri from Taipa who saw that many migrants were more active in politics than the Kaili ethnic. However, Mr. Rustam hoped for the social harmony of Kaili ethnic and other migrants (Bugis ethnic, Makassar ethnic, etc.) as the social harmony of people in Mamboro area.

The interview above presents the notion of society (respondents) about politics either as a term or as an ideology or as a practical social dynamic because politics is a part of human life.

In Palu City, respondents generally face quite a bit of practical politics. At the sub-district level, especially, the political promises, legislative candidates not fulfilling their promises have made them traumatized by politics. This socio-political reality is quite 
a matter of ubiquity because of the credibility of the individual and the level of public trust. However, such a reality remains a variation and a dynamic of multiculturalism (Nawawi, et al., 2012; Lampe, 2010).

\section{Social Relation between Local People with Migrants}

The context of social relations in this section is more individual but it represents the ethnic community. Related to this, it is assumed by various parties that there is a problem in social relations between local people and migrants. This presumption is based on many cases in some parts of Indonesia such as the Dayak ethnic case as a local resident with the Madurese as migrants (Sudagung, 2001). The conflict between the Rongkong people as migrants and the Baebunta as local people in Luwu Utara District, or the conflict between local peoples and migrants in West Kalimantan; including ethnic conflicts in Ambon, Sampit, Sanggauledo, Kupang, Mataram, Poso, and Bima. (Sihbudi \& Nurhasim, 2001; Surata \& Andrianto, 2001; Dwi Aries Tina, 2004; Zakaria, 2000).

However, the results of the St. Hajar N. Aepu, et al. (2015) on conflict in Pasar Inpres Manonda Palu City states that the incident that happened was not a case of SARA, but a problem between market managers and street vendors. A social condition like this is often blown up by the media to shape the public perception (Taufan, 2013).

Concerning the truth of the above presumption, the results of the interview with Mr. Abd. Halim, a local indigenous person in East Palu District, revealed the following:

"For the East Palu area is very wide. People here have social emotional relations. They are quite good because it supported by their economic activity activities. One of them is employees. There are also traders both local residents and Migrants. This is what makes them no inequality in this region."

The same condition also experienced by local indigenous people and migrants in the sub-district Lere of North Palu. The head of RT 1 named Mr. Zawa acknowledged that his community was safe and harmonious until now. Mr. Ahdar, head of sub-district Mamboro, also revealed that its territory has never had a problem of conflict between local people and migrants. This is due to the self-awareness of all citizens to receive each other and the existence of the firmness of the government, especially the sub district in inviting its citizens to realize peace and tranquility together.

\section{Attitudes and Forms of Tolerance between Local Residents and Migrants}

The atmosphere of Palu is or can be categorized as serene. At the same time, it is also coupled with the creation of a deliberate social relationship through the act of tolerance. The act of tolerance according to Fatta Kadir \& Syufri (2017) is in the form of cooperative association.

In the research location, the social action put forward by the government through the lower level of the RT/RW is to prioritize good interaction among the people through tolerance. As stated by Mr. Zawa, as the head of RT in sub-district Lere, and Mr. Risfan, who is a civil servant, that in the most determining factor, tolerance is the aspect of communication. To strengthen tolerance, it occurred various activities by government such as community service, Saturday Clean Program, sports and art competition inter-RT/RW that involved local and migrant people.

Tolerance also occurs in the case of local traditional marriage ceremonies. Mr. Iwan from North Palu District confirmed if there is a wedding party and praying, Kaili ethnic usually invite their neighbors to celebrate and work together as gotong royong. In that context, 
they basically are all together and help each other. He also understands that if there are activities of local residents, they also come and still help, as well as local residents.

\section{Cultural Dialogue between Local People and Migrants}

Cultural dialogue is a formal term commonly used in plural society. Mostly, this activity is also aimed at finding the point of equality of a number of different ethnic cultures in order to realize a harmonious social situation.

In areas with high conflict intensity, cultural dialogue is done formally. These activities bring together the figures of the conflicting parties. In it, they discuss the socio-cultural aspects they possess and their similarities, and then their cultural differences are respected.

In the city of Palu, there are no specific meetings on cultural dialogue between conflict people (Kaili ethnic and Bugis ethnic). Social interactions between ethnic groups take place naturally. If there are social problems that occur, the government solve them at that time.

At the research site, the cultural dialogue is more frightening for Palu residents because it describes the situation of the less conducive community so this cultural dialogue is a solution. However, this term is understood as a daily activity of all citizens of Palu City, both local and migrants who are unifying them. This is revealed by an informant named Mr. Sahdin, the head of Social Section for Community Empowerment in Lolu Selatan sub-district, that cultural dialogue was done by Youth Mosque Council through the religious festival. Meanwhile, the head of Kayu Malue sub-district Mr. Robin understands it as an assimilation.

Based on the description above, it can be concluded that the people of Palu City understand concrete cultural dialogue in the form of the integration of society in everyday life without any quarrels so people of diverse backgrounds can coexist peacefully and harmoniously. They do not understand cultural dialogue specifically in the form of meetings of different groups to talk about and meet their good intentions.

\section{Attitudes of Local Citizens with Inmates Receiving Difference}

Basically, local people in Palu City have an open characteristic of things that are different from their cultural character. It can be understood because every community or ethnic group has the purpose to live harmoniously.

Related to the heterogenity that changes the development that impact to inter-city migration, the migration of other people to Palu city becomes a social consequence. The inevitability also applies to the emergence of various sociocultural backgrounds.

In response to these differences, community leaders and the government of Palu City have the same reaction. Mr. Zawa, an ethnic Kaili who once served as head of RT in Lere Village, stated:

"The way for local harmonization
and migrants to remain in place
is to be able to do meetings in the
neighborhood, the teenage talim
assembly of the mosque, it is possible,
and from the person also if people
want to involve we enter, so usually
the local people can't enter the name
of the newcomer not known."

Specifically, the socio-psychological aspect is the deepest factor in the individual affecting acceptance or rejection. This aspect became the focus of attention. Mr. Iwan in Mamboro, who served as section head at the sub-district office, stated:

"The core aspect of harmonization between local people and migrants is together keep each other in order not to be resentful, but it depend on the attitude of migrants themselves. In 
Mamboro, there are many educated people and no one make trouble to others. in Mamboro there is a lot of unemployment is not because there is no school but because there is no job."

Community activities in the village can unite the local people and migrant people. Mr. Risfan, a local and an employee of the subdistrict Mamboro office, said:

"For example, there are activities and have not thought the ethnicity, for example.... the father even though his ethnic is different... we just invited to the activity whether it is a form of sport or artistic activities, not because of his ethnic but because of his intense and here also there is an RT chairman of different religion Manado people but because active and concerned with the environment then the people there agree. "

Based on the above explanations, there are a number of factors that may serve as guidance in creating harmonious social conditions between local people and migrant people. Among others, the socio-psychological aspect in the form of mutual understanding occurring in social activities integrate people and culture and cause socialization of RT/RW to strengthen the fraternity if there are new citizens.

The Role of People and Institutions in Building Multicultural Awareness

Various views about local people and migrants at the study sites recognize their relationship between them is harmonious. This has been described in the previous descriptions.

However, other views state that the social process cannot just stop there. Various efforts must be done constantly because the life of the people in the future will be more complex and more heterogeneous with interests. This condition will have consequences for the need for various forms and models of harmonization in the future as an alternative.
In the context of this research, efforts to realize the harmonization also continuously carried out by the government and citizens together. Mr. Lawide, a local customary leader from North Palu, said:

"In my neighborhood, there are many community activities that take place both on the initiative of the residents themselves and by the RT/ RW, such as the activities of mothers of the Dasa Wisma group, social gathering of RT/RW, mass-gathering activities every Sunday."

Zuliharianti (a Javanese woman), a teacher in Mamboro Junior High School, also experienced the same thing in a heterogeneous environment. She said there are many activities of women in the neighborhood. These activities include pengajian by taklim assemblies attended by local people and migrants. Through this Majelis Taklim group, they build social solidarity such as visiting each other when there are people who are distressed to provide assistance. They also do social gatherings in turns at the homes of its members. This strategy was able to create a harmonious condition among them.

Utilization of social institutions that exist in the sub-district also occurred in North Palu as told by Mr. Iwan:

"In North Palu, there is a PKK at sub-district. At the sub-district level that exists and we here only know the newly formed institutions, archived here so we know that in this sub district there are institutions that stand, including activities of youth and youth mosque."

In sub-district Mamboro, the awareness of the people to receive each other is also continuously championed by the government in this case of the head of the village. Mr. Ahdar said: 
"Now ni K5 government program is Clean Saturday and I did that, and society is not as easy as turning the palm of the hand to awake them and every week announced in the mosque for Saturday Clean Program. We are with the same work of devotion because the present value the mutual cooperation faded and this is what will rebuild."

The same thing also affirmed by the staff in sub-district Mamboro, Mr. Muhammad Risfan, about various activities promoted by the government. He said that "RT/RW here always holds art activities. In addition, there are also activities of the PKK and majlis taklim". There is also an activity whose name is clean and it's a government activity, and that's great because through these activities people will meet each other. It means that people will mingle together and mingle each other, the kind before in the civil and the citizens who come there are From BTN housing and some from the lower village, and we are equally there, perhaps indirectly there is interaction, creating interaction with those people.

In that case, Mr. Risfan is respectful of diversity as a good and positive thing. He recounts:

"I think the diversity will be positive, because I see the local people here are willing to accept diversity, because as an example with other sub district probably the most migrants are Mamboro village, because it has many public facilities, health schools, there is Brimob, migrants can not make a house here so it gets crowded and uplifting situation."

It can be concluded that the multicultural awareness desired by the Palu community has manifested itself in various social activities as described previously. In addition, the ongoing activities are the result of sub-district initiatives in involving social institutions such as youth, majlis taklim, arisan, PKK, Dasa Wisma, adolescent mosques, local customary institutions, $L P M$ and so on.

\section{Efforts to Achieve Social Integration}

Social integration of all components in society is the hope of all citizens, especially of the government as the responsible body for social harmonization. Various efforts have been made by all components to realize those goals on an ongoing basis.

One concrete step sought by various parties, especially religious communities in realizing such integration, is to establish institutions that take place in the area of religious social integration. This organization is called Religious People Communication Forum (FKUB), which also is supported by the government of Palu City.

The establishment of FKUB is one of the institutional efforts to help the government program thatindirectly nuanced multiculturalism. The response of Palu people about it is quite different. Many of these organizations are not well known by people in Palu City.

Mr. Ahdar in Mamboro stated that he does not know the organization. He only agrees if the organization is formed in the sub district although he prefers to empower and expand the function of existing community organizations in the village, such as youth, mosques, and so forth. He revealed:

"The existing institutions in Mamboro are LPM, PKK, Lembaga Adat, Karang Taruna, Risma, that's all. Some existing institutions can already be a medium of interaction for the community, such as LPM. Through this LPM all the communities in Mamboro all recruited, and the LPM chairman is an migrants but married here, many newcomers can be trusted." 
The role of government in realizing social integration as in Mamboro also done in sub district Taipa. This is stated by Mr. Asri, an officer of the sub district that:

\begin{abstract}
"The current city government with the $\mathrm{K} 5$ program is currently forming a task force team that engaged in this $\mathrm{K} 5$ program in which there is a public peace order program. Therefore, the government plays an important role in society with the differences that continue to socialize as to what the differences are and how we address those differences with different ways of thinking. The government has effort to create people's good mindset, to get the success with the different culture. This is the role of the government as a public servant to continue to intensify the program."
\end{abstract}

Mr. Asri continued that the program is potentially positive for the role. He hopes that the early implementation of the $\mathrm{K} 5$ program will relate to vertical institutions such as TNI, police, youth leaders, religious and traditional leaders. That is what plays in the community through the government program of the mayor, who makes these activities can change in the future and makes the city of Palu in a better direction.

In a further context, the urban village encourages people with different cultures through the current government to conduct activities to provide protection to the community through the "Cleanliness, Beauty, Security, Order and Comfort" program that continues to socialize. It is a common understanding that the different culture and custom will be synergized and people will be integrated so that it avoids various conflicts through the government program. It can not deny if there is a conflict in the community because in the beginning, it is usually caused by the act of young children. However, from a few different years, the people's perspective is much more open, and they are moving with various activities to find their livelihood, especially in the area of North Palu in the industrial area so the emergence of the conflict is unlikely.

Looking at the above description of social integration, it can be concluded that the government in all levels remains the primary initiator and the one responsible. In its implementation, the government becomes the coordinator of the implementer and at the same time, it moves along with various components of the community as localized resources at the institutionalized or organized grass roots such as youth, adolescent mosques, customary institutions, LPMs, and other organizations that have existed before.

\section{The Influence of Multiculturalism on Conflict in Palu City}

The dynamics of the social life of the people of Palu City was colored by clashes between ethnic groups, adherents of the religion and youth groups, but not extending to the Poso riots that lasted from 1998-2005. Nevertheless, the social ripples claimed lives such as inter-village fights, mysterious shootings, bombings of places of worship and public facilities. Such incidents affected the suspicion and lack of mutual respect and caused the diminution of tolerant values among the citizens.

No less than 5 times, there was interethnic conflict between Kaili and Ethnic Bugis in Palu City. The incident of social conflict in August 2006 was quite large because it involved citizens of both ethnic groups (Kaili and Bugis) on a wide scale. Fear, anxiety and even a large number of Bugis ethnic people around the scene of events (in Palu City Inpres Market) were forced to evacuate to other places to avoid the possibility of becoming a victim. Conflict occurred again in July 2009 but in a smaller size than before.

For many people, especially the sociopolitical analysts, the conflict is basically not 
a $S A R A$ conflict but an economic conflict. The government, in this case, the regional market manager, must deal with street vendors who almost all acted by local residents. In almost all conflict between market managers and PKL in Indonesia, the issue of conflict is always about the inability of the PKL to meet all market manager requirements in order to continue their existence in the market.

On the opposition side, traders from Bugis have always been able to meet all market management requirements so they mostly have kiosks in the market environment for selling. This condition leads to social jealousy amongst street vendors as a form of ethnic economic castration. This reality is then blown up by electronic and print media as a form of SARA conflict (Taufan, 2013).

The information became indisputable in the field in various interviews where almost all the respondents of this study stated that the conflicts that happened had nothing to do with SARA but only administrative and management cases. Even some other respondents acknowledge that the social relationship between Kaili ethnic with migrants is normal and there is no friction. Even if there is an argument, it is more related to juvenile delinquency and even directly resolved in kinship in the sub-district.

The secretary of the sub-district East Besusu, Mr. Nurdin, gave a quite interesting statement that the citizens who were in dispute chose not to extend their affairs. He said:

"It seems that now people are already smart, in the sense that they are not arguing with each other like we face to face like this. Maybe they are more directed to the sub district. There is a place supposing to stem them, so, for example, the migrants with the locals let us meet in sub district to solve this problem and let there be no outside noise for example, so like that."
Related to multiculturalism, a community leader of Talise Village, Mr. Rustam also dismissed any potential conflicts that arise anytime. He is convinced that people were increasingly aware of the importance of coexistence in peace and serenity. He said there is a feeling to guard each other, to exist, and to accept each other, and to meet together and solve their local problems.

Looking at some views of respondents about multiculturalism in Palu City, almost all have a positive perception. For them, multiculturalism is an inevitable social necessity. Considering the status of Palu City as the capital province, certainly it has the attractiveness of economics, resources, facilities, entertainment, employment, and so forth that promise for everyone. In this context, heterogeneity and multiculturalism are the dimensions of accompaniment in them.

Multiculturalism as part of an urban dynamic necessarily requires a degree of social integration in order to achieve a balanced social harmonization. Therefore, all societal components need to play an active and progressive role in making it happen.

Various respondents' recognition about multiculturalism as something good and useful indicates that Palu City still has a good level of harmony and good social harmonization. This is shown in one of the industrial areas in Kayu Malue, where a balanced level of dependency between local people as industrial workers requires the presence of migrant residents who work as traders to provide all the needs of these industrial workers.

Another effort also shown by one of the heads of the RT who sees multiculturalism not related to the conflict is holding a visitingeach another event in RT when there are new residents or settlers residing in their area. The activity reaps positive responses from its citizens so there is almost no social problem in its territory. 
Based on the above concrete example, multiculturalism can be positive and provide benefits if every individual has an open attitude that is accepting and mutually understanding of all the differences that exist as a law of nature. Practically, it can realize when accompanied by communicative actions in discussing social issues that occur in all components of society, between individuals and individuals, between individuals with organizations or institutions and between institutions and institutions.

Strategy for Building Integration and Harmonization of Communities in Palu City

Parsons (Poloma, 2004) stated that every social system in a society or community always has its own internal dynamics but the social system is always in a balanced or harmonious state. However, Merton (Ritzer, 2012, p. 428) stated that if in a social system an imbalance occurs, then the cause will be replaced by a new and balanced social system.

The theoretical description by Parson and Merton above illustrates the ongoing multicultural reality in Palu City. The initial assumptions built into this research on multiculturalism as the cause of the conflict are in fact less relevant to use because the social realities in Palu suggest otherwise that no SARA conflicts occur. Indeed what happens is that all individuals have the consciousness and desire to live together in a harmonious social life both with their fellow human beings, as well as with nature and God.

Awareness to live in harmony, indicating a concrete effort to make it happen in the form of social action. Such social action always contains elements of rationality on the consideration of profit and loss, rationality for reasonable achievement, and the rationality of the fit between effort and target.

Based on various interviews in the previous section, concrete efforts meant by respondents are always directly related to the social problems that occur in their environment. However, the overall effort that people generally do is to build social groups by utilizing their local resources. The social groups that formed are; (1) Custom Institution in all sub-districts; (2) Mosque Forum and Forum Board Mosque in all sub-districts; (3) Forum Talise Unite Society at sub-district of Talise; (4) Productive Young People in all sub-districts; (5) Community Information Group in sub-district Besusu Barat; (6) Dasa Wisma Group all subdistrict area. (7) Teens Mosque Group in all sub-districts; (8) Arisan Group of RT/RW in all sub-districts; (9) Make group of Majelis Taklim in all sub-districts, (10) Religious Harmony Forum (socialization stage of the province).

Through coordination with the subdistrict, all the above social organizations run each work program based on the characteristics of the organization. However, the existence of the social organization at the grassroots level has impacts on the high intensity and frequency of interaction and communication of people in their areas.

Based on the results of interviews, various respondents at the research sites of North Palu and East Palu stated that all social organizations supported directly by the government through various activities so that all organizations are active in the community with its various programs.

At the sub-district level, urban village governments generally run their programs seriously. Interviews with respondents from Mamboro, Talise, Taipa, Kayu Malue and some 'sub district' officials stated that they have community programs that oriented towards the social integration of their citizens. In general, the work program is (1) Clean Saturday Program, (2) PK 5 Program, (3) RT/ RW Visiting Program, (4) Sport and Art of Subdistrict Program.

All these activities have been going on for a long time and are routinely where the sub districts are held. The target they set they can meet though not significant. The results evidenced by the awareness of citizens 
to mutual acceptance, mutual openness, mutual help, mutual assistance in various social activities as the interviews of previous respondents.

Although all respondents stated that there were no conflicts and no problems between locals and migrants, the urban village still needed to take anticipatory steps against other social issues that could arise. Social issues among adolescents recognized by many respondents frequently. In this context, the role of 'Sub district' in establishing 'People Maintaining' institution becomes effective its existence. Through this institution, many issues of adolescent conflict can resolve amicably at the sub district level so the issue is not widespread and does not need to be taken to the police station. Nevertheless, the urban village keeps in contact with the police as a form of institutional appreciation including with the TNI in creating a comfortable and harmonious social condition.

The multiculturalism development in Palu city concerning economic, social, and political aspects have their each dynamics. In the economic field, it generally dominated by Migrants from medium to large scale, whereas most locals engaged in small economies. However, in some cases, local citizens and migrants need each other. Related to social aspects, local residents and migrants generally have a harmonious relationship, mutual understanding, and respect. The political aspect, it dominated by citizens of Migrants in status by maintaining cooperation with local people mutually. This social realities indicate that multiculturality is not the cause of conflict but multiculturalism made a positive trigger by the people of Palu City to realize a harmonious life.

In order to actualize the harmonious life, the form of strengthening is to establish cooperation with all local resource-based sociocommunity institutions, while the strategy pursued is empowering, providing incentives for social-community institutions.
Looking at the above descriptions, the results of this study confirmed by the analysis of Santosa (Hadi, 2017, p. 8), which examines intercultural communication in his research entitled "Intercultural Communication in a Plural Society in Palu Central Sulawesi (Study of the Effectiveness of Intercultural Communication Kaili, Bugis, and Toraja)." The results of this study indicate that maintaining effective communication between the Kaili, Bugis, and Toraja tribes was caused by activities involving the three ethnic groups. These community activities are mobile security systems, work services, sports, and other activities. Although their activities are simple, they felt its benefits and it proved that one thing that can make communication effectively in the city of Palu Central Sulawesi Province is the high frequency of meetings between people both inter-ethnic and among-ethnic. Local security system (Siskamling) and village sports are the best solutions.

Other studies strengthening the findings of this study are the works of (1) Masdar et al. (2014) about on 'Budaya Etnik dan Keserasian Sosial' (Ethnic Culture and Social Harmony) which found that inter-ethnic of social harmony manifested through the same interpretation in achieving the goals of living together; (2) Halim et al. (2017) on 'Diversitas dan Keserasian Sosial: Studi Makna Multikulturalisme di SMAKatolik Rajawali Makassar dan MAN Insan Cendekia Gorontalo (Diversity and Social Harmony: study of the meaning of multiculturalisme in SMA Katolik Rajawali Makassar and MAN Insan Cendekia Gorontalo) also found that factors that can unite diverse communities are common interpretations of common goals.

Based on the findings, it can be described that social harmonization can be realized through mutual understanding of the purpose of living together in groups or communities. Ethnic and religious differences cannot be lost, but they can be managed into potential resources to understand each other. 


\section{Conclusion}

There two matters conclude in this section as the way of institutional strengthening. They are about government efforts and local people efforts.

In answering the question about the efforts of institutional strengthening at the grassroots level of Palu people in creating the social life harmony, both government and people cooperate together. Government works by using its power and authority; people work by involving, supporting, and applying the government policy.

In the policy level, government created local institution as mentioned above. Through this local institution, local people have a social space legally to articulate their common interest. In this local group, everyone has played its roles to build the social harmony.

In grassroots, people are involved in every program and local institution. Through those programs, all people in every sub-district area will unite together to involve inside. Through the institutions, people channeled their ideas, skills, and capabilities.

To strengthen these social institutions and people role in making social harmony, that social institutions should improve their social role and expand their networks to other institutions in other regions to the district and provincial levels.

\section{References}

Aepu, S., Tang, M., \& Basir, M. (2015). Penyelesaian konflik di Pasar Inpres Manonda Kota Palu Sulawesi Tengah (Unpublished master's thesis). Postgraduate of Hasanuddin University.

Hadi, F. (2017). Komunikasi antarbudaya pada mahasiswa Bangka-Sunda (studi etnografi komunikasi kedwibahasaan pada mahasiswa Bangka-Sunda di FISIP UNPAD Bandung). (Unpublished master's thesis), Universitas Pasundan Undergraduate Library.
Halim, H., As'ad, M., Bahri, S., \& Zainuddin, R. (2017, July 17). Diversitas dan keserasian sosial: studi makna multikulturalisme di SMA Katolik Rajawali Makassar dan MAN Insan Cendekia Gorontalo). In The $1^{\text {st }}$ Qualitative Research for Civilization Conference (QRCC) (pp. 1689-1703). Surabaya: IQRA \& FISIP Universitas 17 Agustus 1945 Surabaya.

Kadir, F., \& Syufri. (2017). Pola interaksi antar etnis (studi sosiologis tentang interaksi sosial Suku Kaili - Suku Bugis di sub district Donggala Kodi Kecamatan Ulujadi Kota Palu). Jurnal Sosial Nusantara (JSN), 1(1), 1-12.

Lampe, I. (2010). Identitas etnik dalam komunikasi politik. Jurnal Ilmu Komunikasi, 8(3), 299-313.

Masdar, M., Halim, H., Zainuddin, R., \& Zainuddin, F. (2014). Budaya etnik dan keserasian sosial. In The $1^{\text {st }}$ Academic Symposium on Integrating Knowledge (pp. 391-398). Johor: Ibnu Sina Institute for Fundamental Science Studies, Universiti Teknologi Malaysia.

Nawawi, M., Anriani, H. B., \& Lampe, I. (2012). Dinamika etnisitas dan konflik politik pada Pemilukada Kabupaten Poso. Jurnal Kebudayaan dan Politik Universitas Airlangga, 25(3), 223-232.

Poloma, M. (2004). Sosiologi kontemporer. Jakarta: PT. Raja Grafindo Persada.

Ritzer, G. (2012). Teori sosiologi klasik sampai perkembangan terakhir posmodern, edisi kedelapan. Yogyakarta: Pustaka Pelajar.

Sihbudi, R. \& Nurhasim, M. (2001). Kerusuhan sosial di Indonesia; studi kasus Kupang, Mataram, dan Sambas. Jakarta: Grasindo.

Sudagung, H. S. (2001). Mengurai pertikaian etnik migrasi swakarsa etnis Madura ke Kalimantan Barat. Jakarta: ISAI, Yayasan Adikarya, IKAPI, dan Ford Foundation.

Surata, A., \& Andrianto, T. T. (2001). Atasi konflik etnis. Yogyakarta: Global Pustaka Utama.

Taufan, M. B., (2013). Pengaruh pemberitaan surat kabar terhadap prasangka agama di 
Kota Palu (Suatu Kajian Sosiologi Hukum Islam). ISTIQRA', Jurnal Penelitian Ilmiah P3M STAIN Datokarama Palu, 1(1), 23-57.

Tina, D. A. (2004). Kekerasan komunal dan damai studi dinamika dan pengelolaan konflik sosial luwu. (Unpublished master's thesis). Postgraduate of Hasanuddin University.
Utsman. (2007). Analisis konflik sosial. Yogyakarta: UGM Press.

Zakaria. (2000). Konflik sosial pada masyarakat majemuk: kasus Desa Se'pon dan Pelalan kecamatan lamasi Kabupaten Luwu. (Unpublished master's thesis). Postgraduate of Hasanuddin University. 